\title{
PRELIMINARY Rb-Sr AGE DETERMINATIONS FROM THE NORTH GREENLAND FOLD BELT, JOHANNES V. JENSEN LAND, WITH COMMENTS ON THE METAMORPHIC GRADE
}

\author{
Niels Springer
}

This report presents the first $\mathrm{Rb}$-Sr age determinations obtained on low-grade metasediments within the eastern part of the North Greenland fold belt. Samples were collected during the 1979 field mapping in eastern Johannes V. Jensen Land, the results of which have been published elsewhere (Soper et al., 1980). Material selected for this study was taken from moderately folded rocks of the Polkorridoren Group and from the northern part of the fold belt where deformation is intense and sedimentary structures are rarely preserved (fig. 23).

The principles and methods of isotopic dating of sedimentary rocks applied in this study have been treated in a recent paper by Clauer (1979).

\section{Sampling}

From the collections made during the 1979 expedition, two localities were selected for the preliminary study reported here (fig. 23).

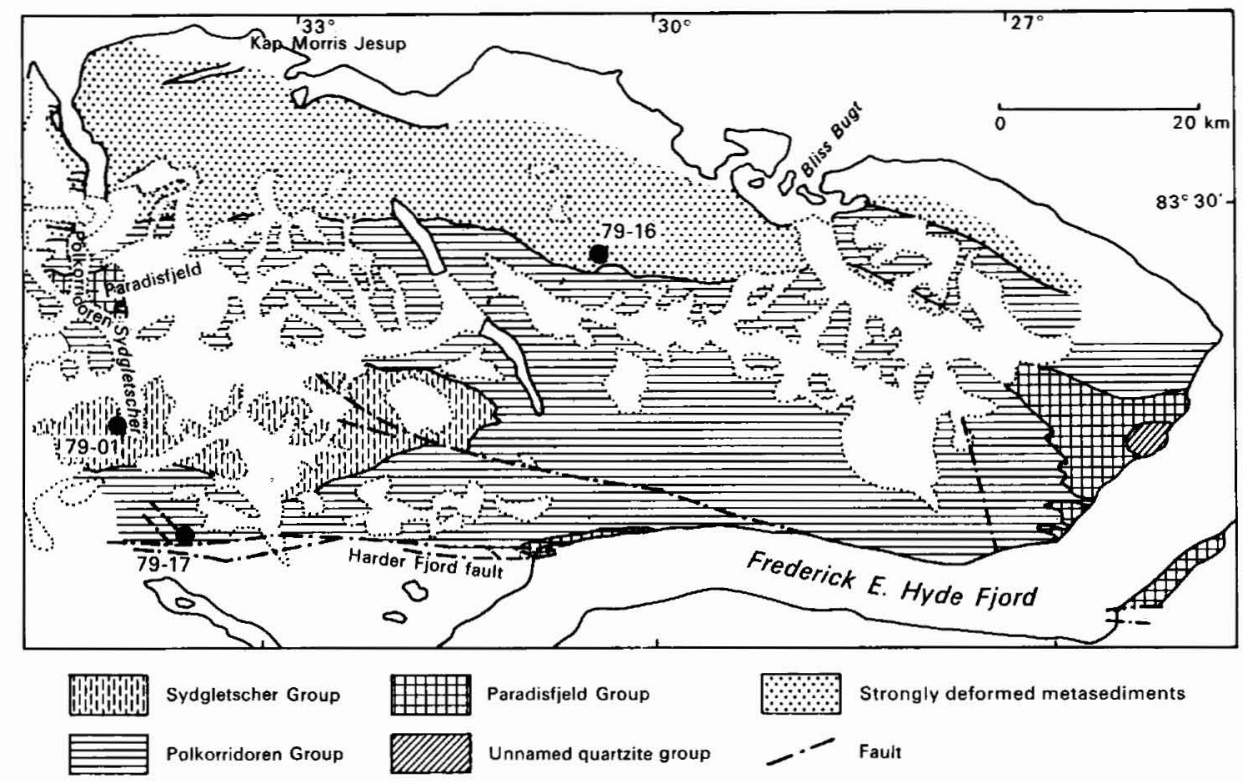

Fig. 23. Simplified geological map of eastern Johannes V. Jensen Land showing the position of the sample localities. 
Purple slate, loc. 79-16. This recessive unit in the northern part of the fold belt is strongly deformed and in places chevron folded. $S_{2}$ is the dominant cleavage. The primary bedding is still just discernible and deformed flute casts were found in a few interbedded sandstones.

Shale (Polkorridoren Group), loc. 79-17. Shale samples and a sample of a fine grained calcareous sandstone were collected from a thin-bedded turbiditic sequence from the lower part of the Polkorridoren Group, situated about $2 \mathrm{~km}$ north of the Harder Fjord fault. Major, upright $F_{1}$ folds dominate this southern part of the fold belt (Dawes \& Soper, 1979; Soper et al., 1980). An associated planar fabric is not normally seen, but at this locality a very weak low-angle cleavage $\left(S_{2}\right.$ ?) is developed in most of the interbedded shales from which the samples were collected. Detrital white mica was found in silt and sandstones from this sequence.

Sampling was restricted to a limited area of outcrop, i.e. within a diameter of $200 \mathrm{~m}$. This was decided upon because isotopic homogenization on a large scale could not a priori be expected to occur in this type of low-grade clastic metasediments.

\section{Analytical techniques and precision}

The samples were gently crushed to pass a $0.5 \mathrm{~mm}$ sieve. This procedure was followed to prevent excessive reduction of the sample grain size. The clay fraction (fraction $<2 \mu$ ) was separated using a particle size centrifuge. Samples containing carbonate were treated with $1 \mathrm{M}$ acetic acid for 48 hours at $40^{\circ} \mathrm{C}$ before separation in the centrifuge.

$\mathrm{X}$-ray diffractometry was performed on both whole-rock material and the clay fraction. Unoriented and oriented specimens were prepared of the clay fraction and different treatments (saturation with $\mathrm{K}^{+}, \mathrm{Mg}^{++}$, glycolation and heating to $550^{\circ} \mathrm{C}$ for 1 hour) facilitated the mineral identification.

$\mathrm{Rb}$ and $\mathrm{Sr}$ contents as well as $\mathrm{Rb} / \mathrm{Sr}$ ratios were determined by $\mathrm{X}$-ray fluorescence spectrometry, using USGS G-2 as standard ( $\mathrm{Rb} / \mathrm{Sr}=0.355$, Pankhurst \& O'Nions, 1973). $\mathrm{Sr}$-isotope ratios were measured on unspiked preparations, corrected for fractionation and normalized to 0.7080 for the Eimer \& Amend $\mathrm{SrCO}_{3}$ standard. The program developed by McIntyre et al. (1966) with minor corrections (Brooks et al., 1972) was used in the linear regression analysis. Experimental precision was 1.4 per cent in ${ }^{87} \mathrm{Rb} /{ }^{86} \mathrm{Sr}$ ratios and 0.0004 in ${ }^{87} \mathrm{Sr} /{ }^{86} \mathrm{Sr}$ ratios, except sample no. $219961 \mathrm{Ac}$ which was assigned an error of 8.4 per cent in the ${ }^{87} \mathrm{Sr} /{ }^{86} \mathrm{Sr}$ ratio due to the very low $\mathrm{Rb}$ content. This sample is the extracted carbonate component from a calcareous sandstone. The assigned experimental precisions are based on 20 duplicates. $\mathrm{Rb}$ and $\mathrm{Sr}$ concentrations given i Table 1 are precise within 5 per cent. All statements of precision are given at the $2 \sigma$ confidence level. The bounds quoted with the age and initial $\mathrm{Sr}$-isotope ratio are the $2 \sigma$ confidence limits as well. Ages were calculated using the decay constant $\lambda^{87} \mathrm{Rb}=1.42 \times 10^{-11} \mathrm{a}^{-1}$.

\section{Mineralogy}

\section{Results}

The X-ray diffractogram shown in fig. 24 can be taken as characteristic for both localities. The narrow, well-defined peaks indicate that material of good crystallinity is present in the clay fraction.

Muscovite. In the oriented specimens $\mathrm{Mu} \mathrm{d}(002), \mathrm{d}(006)$ and $\mathrm{d}(00.10)$ basal spacings yielded the strongest reflections. The different treatments had no effect on $\mathrm{Mu}$ basal spacings. The strong peak at $9.97 \AA$ is a composite of muscovite and paragonite (002) reflec- 




Fig. 24. X-ray diffractogram of a typical clay fraction sample from locality $79-16$. Oriented mount showing only basal reflections. Abbreviations: $\mathrm{chl}=$ chlorite, $\mathrm{mu}=$ muscovite, $\mathrm{pa}=$ paragonite, $\mathrm{pa} / \mathrm{mu}$ $=$ mixed-layer paragonite/muscovite, $\mathrm{qz}=$ quartz.

tions. Due to this composite peak 'illite crystallinity' measurements (Kübler, 1967) have not been carried out. A comparison between an unoriented diffractogram and data recorded for synthetic muscovite (Yoder \& Eugster, 1955) identifies the major peaks characteristic of a $2 \mathrm{M}_{1}$ muscovite. The polymorphic modifications were determined according to a method applied by Velde \& Hower (1963), and both the $2 \mathrm{M}_{1}$ and the $1 \mathrm{M}_{\mathrm{d}}$ polymorphs were detected in the following proportions: $2 \mathrm{M}_{1} /\left(2 \mathrm{M}_{1}+1 \mathrm{M}_{\mathrm{d}}\right)=30-50$ per cent. The $1 \mathrm{M}$ polymorph was not found.

Paragonite. This mineral can be distinguished by the position of the basal reflections (004), (006) and (00.10) (Chatterjee, 1971; Frey, 1978). Saturation with $\mathrm{K}^{+}$and $\mathrm{Mg}^{++}$as well as ethylene glycol treatment had no effect on this mineral. However, heating to $550^{\circ} \mathrm{C}$ for 1 hour decreased the intensity of the peaks considerably (fig. 24).

Mixed-layer paragonite/muscovite. As pointed out by Frey $(1969,1978)$, this mineral can be identified from the basal reflections at $3.25 \AA$ and $1.96 \AA$. On heating, the reflections either disappeared or left a flat plateau on the diffractogram. Other treatments had no significant effect.

Chlorite. The position of the (001) basal reflection, as determined from the (004) spacing, was very close to $14.1 \AA$ for all the samples. The first five basal reflections appeared on the diffractogram. Saturation and glycolation had no effect on the position of the chlorite peaks, but heating increased the (001) peak, while all higher order peaks decreased in intensity (fig. 24). Treatment with boiling $2 \mathrm{~N} \mathrm{HCl}$ for $1 / 2$ hour removed all the chlorite reflections and the 


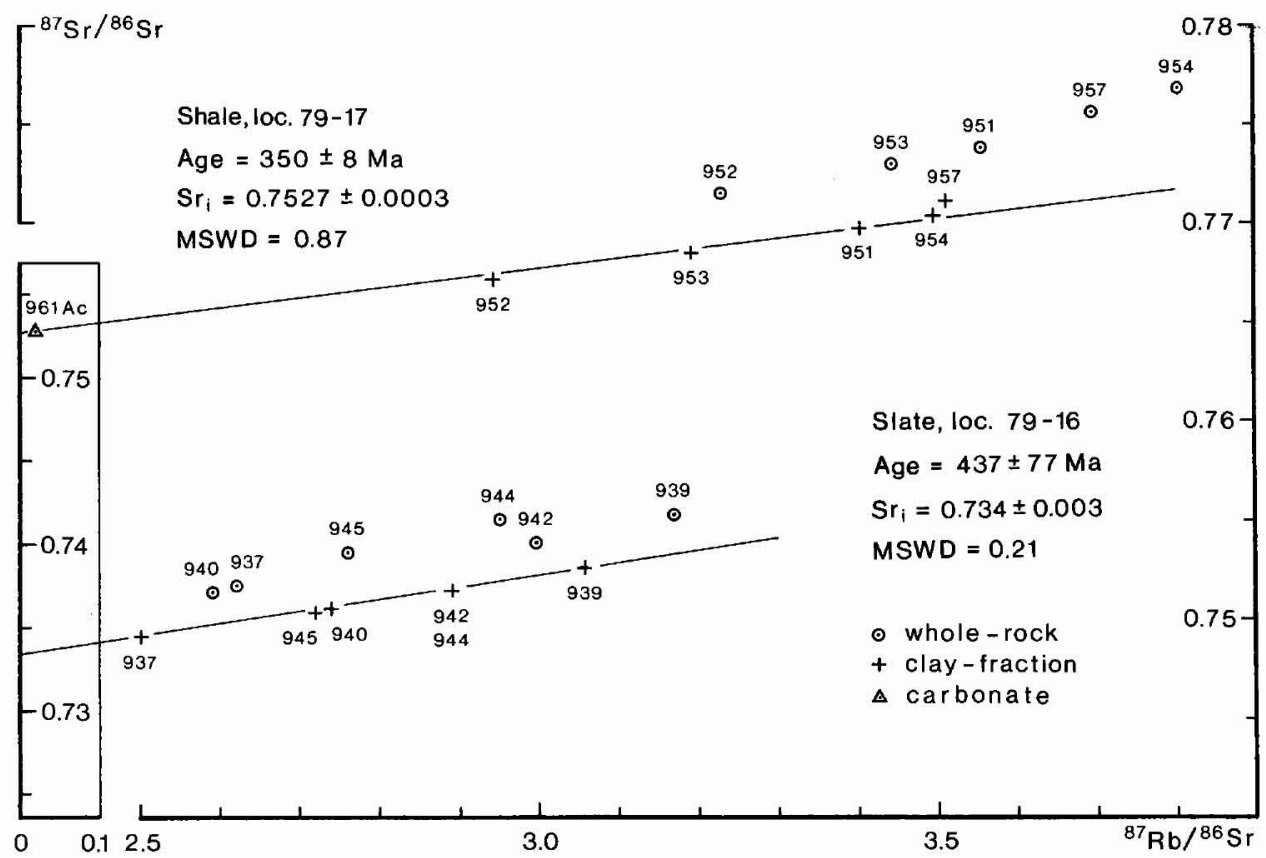

Fig. 25. Rb-Sr isochron diagram for clay fractions obtained from shales and slates in the Polkorridoren Group (loc. 79-17) and the northern part of the fold belt respectively (loc. 79-16). The position of the whole-rock samples is shown for comparison. The last three digits only of the sample number are indicated.

possible presence of a $7 \AA$ mineral, e.g. kaolinite, could be excluded. This conclusion was also reached after inspection of diffraction spectra obtained on unoriented samples.

Other minerals. Quartz and very small amounts of graphite were present in the samples. No feldspar could be detected in any of the samples.

Fraction $>2 \mu$. The mineral assemblage found in the clay fraction was also present in the fraction $>2 \mu$. This is thought to be due to the fine grain size of the overall sample. However, from the intensity of the peaks it was concluded that quartz and muscovite dominated the coarse fraction. Feldspar was not found in this fraction either.

\section{Age and isotope geology}

Both whole-rock and clay fractions were studied from the two localities. As can be seen from fig. 25 the whole-rock measurements do not generate an isochron. It is obvious that isotopic equilibrium was not established in the whole-rock systems. The clay fractions plot relatively close to the whole-rock system in an isochron diagram, but in contrast to the latter they define good isochrons (fig. 25). The clay fractions from loc. 79-16 define an age of 437 $\pm 77 \mathrm{Ma}$ with an intercept at $0.734 \pm 0.003$ and a MSWD $=0.21$. The clay fractions and the carbonate component from loc. 79-17 plot on an isochron with an age of $350 \pm 8 \mathrm{Ma}$ and initial ratio $0.7527 \pm 0.0003(\mathrm{MSWD}=0.87$ ). Sample no. 219957 falls somewhat off the line and was excluded from the regression analysis. The $\mathrm{X}$-ray diffraction study did not offer 
any explanation for this deviation. If this sample is included in the regression analysis the age and initial ratio do not change significantly, but the MSWD-value increases to 3.37 and the line is no longer an isochron (limiting F-value is 2.87 at the 95 per cent confidence level).

\section{Discussion}

Earlier attempts to date the expected Palaeozoic deformation and metamorphism in the fold belt have not been successful. K/Ar mineral and whole-rock dating on the high-grade rocks west and south west of Kap Morris Jesup (fig. 23) has yielded Cretaceous to Tertiary ages pointing to a much younger event in this part of the fold belt (Dawes \& Soper, 1971).

Dawes \& Soper (1979) considered the sedimentary succession to be of mainly Lower Palaeozoic age, probably reaching into the Devonian. With the discovery of age-diagnostic graptolites of Lower Llandovery age from the upper part of the Upper Sydgletscher Shales (Surlyk et al., 1980), most of the Sydgletscher Group could be referred to the Ordovician, and the uppermost unit, the Sydgletscher Sandstone, to the Silurian. The age of orogenesis, from geological considerations, is considered to be between late Silurian and Carboniferous time (Dawes \& Soper, 1979; Surlyk et al., 1980).

The ages presented from localities 79-16 and 79-17 are considered to date a structuralmetamorphic episode in the fold belt. This can be understood by considering the close isotopical agreement between the whole-rock samples and the clay fractions, as well as the high initial ratios characterizing the isochrons (Clauer, 1979). New formed clay minerals and carbonate precipitating from a marine environment will record the value for the contemporary common $\mathrm{Sr}$ in the marine environment. The initial $\mathrm{Sr}$-isotope ratio could then be expected to occur in the range 0.7065 to 0.7095 for Phanerozoic rocks (Faure \& Powell, 1972) not subjected to later disturbances. The high initial $\mathrm{Sr}$-isotope ratios recorded from the two localities emerged as a result of a metamorphic recrystallization and $\mathrm{Sr}$-isotope homogenization of older, detrital material.

It was pointed out earlier, that the whole-rock material is dominated by quartz and (detrital) muscovite (mainly the $2 \mathrm{M}_{1}$ polymorph). The whole-rock samples failed to give isochrons, while the clay fractions define good isochrons. This proves that the clay fraction, as well as the high component of the $2 \mathrm{M}_{1}$ muscovite polymorph present in the clay fraction, recrystallizes and homogenizes isotopically when subjected to a low-grade metamorphic event. This conclusion has also been reached by others (see e.g. Clauer, 1979; Clauer \& Kröner, 1979).

Unfortunately the isochron age from loc. 79-16 can only be given with a considerable uncertainty. This is primarily due to the small range in $\mathrm{Rb} / \mathrm{Sr}$ values (fig. 25 and Table 1). Considering that the true age, at the 95.5 per cent level of confidence, is to be found in the period from Upper Cambrian to Upper Devonian, this estimate of the Palaeozoic deformation and metamorphism is of little value compared with the geological determination (Upper Silurian to Upper Carboniferous).

The clay fractions and the carbonate from loc. 79-17 do, however, define a precise isochron age indicating a structural-metamorphic episode in the North Greenland fold belt in Late Devonian to very Early Mississippian time. Considering now the Canadian part of the Innuitian orogenic belt, the major tectonic episode is the Ellesmerian orogeny which occurred from Middle Devonian until Early Pennsylvanian time (Trettin \& Balkwill, 1979). Very few isotopic ages are available from the Canadian part of the orogenic belt. K/Ar age 
Table 1. Analytical results for clay fractions from shales and slates collected in the eastern part of the North Greenland fold belt

\begin{tabular}{llllll}
\hline Locality & $\begin{array}{l}\text { Sample } \\
\text { GGU no. }\end{array}$ & $\begin{array}{l}\text { Rb } \\
\text { Ppm }\end{array}$ & $\begin{array}{l}\text { Sr } \\
\text { Ppm }\end{array}$ & ${ }^{87} \mathrm{Rb} /{ }^{86} \mathrm{Sr}$ & ${ }^{87} \mathrm{Sr} /{ }^{86} \mathrm{Sr}$ \\
\hline $79-16$ & 219937 & 249 & 288 & 2.499 & 0.7492 \\
& 219939 & 260 & 246 & 3.057 & 0.7527 \\
& 219940 & 250 & 264 & 2.738 & 0.7506 \\
& 219942 & 264 & 265 & 2.883 & 0.7515 \\
& 219944 & 252 & 252 & 2.886 & 0.7514 \\
& 219945 & 268 & 284 & 2.723 & 0.7504 \\
& 219951 & 262 & 224 & 3.403 & 0.7698 \\
& 219952 & 261 & 257 & 2.941 & 0.7672 \\
& 219953 & 258 & 234 & 3.193 & 0.7685 \\
& 219954 & 275 & 230 & 3.497 & 0.7704 \\
& 219957 & 250 & 208 & 3.512 & 0.7711 \\
& $219961 \mathrm{Ac}$ & $\mathrm{n.d}$. & $\mathrm{n} . \mathrm{d}$. & 0.0198 & 0.7528 \\
& & & & 0.0198 & 0.7529 \\
\hline
\end{tabular}

n.d. = not determined.

The preparation of No. 219961 Ac was measured twice on the mass spectrometer. Analytical details are given in the text.

determinations on biotite from a granitic intrusion within the northern Ellesmere fold complex have given ages of $360 \pm 25 \mathrm{Ma}$ and $345 \pm 15 \mathrm{Ma}$ respectively (Trettin \& Balkwill, 1979), which are identical inside the error brackets.

To conclude this very preliminary study, a tectono-metamorphic event affected the Polkorridoren rocks of loc. 79-17 in Upper Devonian - Lower Mississippian time. This event is contemporaneous with the Ellesmerian orogeny of the Canadian Arctic.

\section{Metamorphism}

An outline of the metamorphism in the North Greenland fold belt was presented by Dawes \& Soper (1973). The mineralogical composition of slates and shales from localities 79-16 and 79-17 was presented earlier in this paper. In the Upper Sydgletscher Shales (Sydgletscher Group, loc. 79-01, fig. 23), which are presently under investigation, the following mineral assemblage was found in clay fractions and whole-rocks: muscovite + quartz + chlorite + mixed-layer paragonite/muscovite + calcite. Pure paragonite was not found.

To conclude, the X-ray diffraction study has revealed the presence of the mineral assemblage quartz + muscovite \pm paragonite + chlorite + mixed-layer paragonite/muscovite \pm calcite in pelitic lithologies from different sites and stratigraphic levels in the fold belt 
sequence. This is taken as a further proof that a metamorphic episode of regional importance affected the rocks. Despite the northward increase in deformation, which is clearly visible in the field, no difference in metamorphic grade could be detected from the samples studied here.

The same metamorphic mineral paragenesis found in the North Greenland rocks has previously been described by Frey (1978) from a black shale formation in the Central Swiss Alps. He related this paragenesis to the anchizone or lower epizone (very low-grade metamorphism of Winkler, 1976). The $P-T$ conditions of the anchizone were estimated to be $1-2 \mathrm{~kb}$ at $200-300^{\circ} \mathrm{C}$.

Acknowledgements: I wish to thank J. C. Bailey, A. K. Higgins and O. Larsen for critical reading of the text. The study was supported by the Danish Natural Science Research Council.

\section{References}

Brooks, C., Hart, S. R. \& Wendt, I. 1972: Realistic use of two-error regression treatments as applied to rubidium-strontium data. Rev. Geophys. Space Phys. 10(2), 551-577.

Chatterjee, N. D., 1971: Phase equilibria in the Alpine metamorphic rocks of the environs of the Dora-Maria massif, western Italian Alps. Neues Jb. Miner. Abh. 114, 181-245.

Clauer, N. 1979: A new approach to Rb-Sr dating of sedimentary rocks. In Jäger, E. \& Hunziker, J. C. (edit.) Lectures in Isotope Geology, 30-51. Berlin: Springer.

Clauer, N. \& Kröner, A. 1979: Strontium and argon isotopic homogenization of pelitic sediments during low-grade regional metamorphism: The Pan-African Upper Damara sequence of Northern Namibia (South West Africa). Earth planet. Sci. Lett. 43, 117-131.

Dawes, P. R. \& Soper, N. J. 1971: Significance of K/Ar age determinations from northern Peary Land. Rapp. Grønlands geol. Unders. 35, 60-62.

Dawes, P. R. \& Soper, N. J. 1973: Pre-Quaternary history of North Greenland. In Pitcher, M. G. (edit.) Arctic Geology. Mem. Amer. Ass. Petrol. Geol. 19, 117-134.

Dawes, P. R. \& Soper, N. J. 1979: Structural and stratigraphic framework of the North Greenland fold belt in Johannes V. Jensen Land, Peary Land. Rapp. Grønlands geol. Unders. 93, 40 pp.

Faure, G. \& Powell, J. L. 1972: Strontium Isotope Geology. 188 pp. Berlin: Springer.

Frey, M. 1969: A mixed-layer paragonite/phengite of low-grade metamorphic origin. Contr. Miner. Petrol. 24, 63-65.

Frey, M. 1978: Progressive low-grade metamorphism of a black shale formation, central Swiss Alps, with special reference to pyrophyllite and margarite bearing assemblages. J. Petrol. 19(1), 93-135.

Kübler, B. 1967: La cristallinité de l'illite et les zones tout à fait supérieures du métamorphisme. In: Étages tectoniques, Colloque à Neûchatel, 105-122.

McIntyre, G. A., Brooks, C., Compston, W. \& Turek, A. 1966: The statistical assessment of Rb-Sr isochrons. J. Geophys. Res. 71, 5459-5468.

Pankhurst, R. J. \& O'Nions, R. K. 1973: Determination of Rb/Sr and ${ }^{87} \mathrm{Sr} /{ }^{86} \mathrm{Sr}$ ratios of some standard rocks and evaluation of X-ray fluorescence spectrometry in Rb-Sr geochemistry. Chem. Geol. 12, 127-136.

Soper, N. J., Higgins, A. K. \& Friderichsen, J. D. 1980: The North Greenland fold belt in eastern Johannes V. Jensen Land. Rapp. Grønlands geol. Unders. 99, 89-98.

Surlyk, F., Hurst, J. M. \& Bjerreskov, M. 1980: First age-diagnostic fossils from the central part of the North Greenland fold belt. Nature 286, 800-803.

Trettin, H. P. \& Balkwill, H. R., 1979: Contributions to the tectonic history of the Innuitian Province, Arctic Canada. Can. J. Earth Sci. 16, 748-769. 
Velde, B. \& Hower, J. 1963: Petrological significance of illite polymorphism in Palaeozoic sedimentary rocks. Am. Miner. 48, 1239-1254.

Winkler, H. G. F. 1976: Petrogenesis of Metamorphic Rocks. 334 pp. Berlin: Springer.

Yoder, H. S. \& Eugster, H. P. 1955: Synthetic and natural muscovites. Geochim. cosmochim. Acta 8, 225-280. 